Brit. J. vener. Dis. (1964), 40, 118.

\title{
PENICILLIN FAILURES IN GONORRHOEA: RESPONSES TO PROCAINE BENZYL PENICILLIN G AND TO AMPICILLIN*
}

\author{
BY \\ R. R. WILLCOX \\ St. Mary's Hospital, London
}

There is considerable evidence of increasing failure rates following the treatment of gonorrhoea with penicillin (Mead, Moon, and Bean, 1960; Willcox, 1961 ; Sabath and Kivlahan, 1961). Doses and preparations of penicillin sufficient a decade ago have become no longer so in many areas.

The reasons for failure are manifold and complex. They include re-infection, which is probably common but extremely difficult to prove, misdiagnosis (other Neisseria and Mimeae being mistaken for the gonococcus in failing cases), and failure of the penicillin to reach the focus of infection in adequate amounts. The latter can arise from inadequate or faulty penicillin preparations, inadequate absorption or too rapid elimination of penicillin from a "walledoff" focus of infection-particularly in the femaleand also, theoretically, from antagonism to penicillin of penicillinase produced by commensal organisms or by immunological phenomena in the host.

The reason most generally suspected has been a lessened sensitivity of the gonococcus to antibiotics, although it is likely that a number of factors act in concert. The gonococcus has a wide range of sensitivity to penicillin but there is some considerable evidence, not only in Great Britain (CradockWatson, Shooter, and Nicol, 1958; Curtis and Wilkinson, 1958) but also on the continent of Europe (Reyn, Korner, and Bentzon, 1961 ; Roiron, Rasetti-Nicod, and Durel, 1961; Gjessing, 1962; Röckl, 1962) and in the U.S.A. (Thayer, Field, Perry, Martin, and Garson, 1961), of an increasing number of circulating strains less sensitive to penicillin and also of a widening of their range of sensitivity. Moreover, there is also good indication (Cradock-Watson and others, 1958; Curtis and Wilkinson, 1958; Gjessing and Ödegaard, 1962) that

* Received for publication January 3, 1964. the failures which follow treatment with penicillin tend to occur in patients in whom the gonococci can be shown to be less sensitive before treatment. Complete resistance to penicillin is not noted, but rather a lessened sensitivity.

The situation, however, is patchy both geographically, in so far as not all areas are yet affected by this phenomenon, and as regards time (Medical Research Council, 1961) in so far as considerable fluctuation occurs. Improvement is noted, both in the numbers of less sensitive strains and in the clinical failure rates, if treatment practices are changed so as to provide higher serum levels of penicillin to overcome the less sensitive strains (Letchner and Nicol, 1961; Morton, 1963). It is noteworthy that the sulphonamides, which 10 years ago had become virtually inactive in gonorrhoea, have to-day recovered a measure of their powers, at least in laboratory tests, since they ceased to be generally used in this condition.

If "resistance" to penicillin is only relative, that to streptomycin, when present, is usually absolute; moreover, it has been noted that strains showing lessened sensitivity to penicillin are frequently resistant to streptomycin (Durel, 1961; Reyn, 1961). Other antibiotics infrequently used in gonorrhoea (e.g. the tetracyclines, chloramphenicol, erythromycin) remain unblunted, although some changes towards lessened sensitivity of gonococci, as with penicillin, have been reported against the tetracyclines.

There are numerous other antibiotics which can be given in cases of penicillin failure. In view of the frequent concurrent resistance to streptomycin, this antibiotic is best avoided. Otherwise there is a choice of penicillin in high doses, the tetracyclines, chloramphenicol, erythromycin, spiramycin, oleandomycin, and actinospectacin. It has been suggested 
from studies in vitro that one of the newer semisynthetic orally-administered penicillin compoundsampicillin-may be more effective than benzyl penicillin against the strains of gonococci which are less sensitive to penicillin (Ödegaard, 1962).

To test this hypothesis the present paper compares the results in a small series of male cases of acute gonorrhoea re-treated with procaine penicillin after failure with ampicillin, with those in another series of males re-treated with ampicillin after failure with procaine penicillin.

\section{(1) Failures after Ampicillin Re-treated with Procaine Penicillin}

Cases.-24 male patients with acute gonorrhoea were failures to treatment with ampicillin. Of these, eleven were Negroes from the West Indies, eight were from the United Kingdom, three from Eire, and two from Malta; 21 were married and three were single. Their average age was $26 \cdot 3$ years (range 16 to 48 ).

Only eleven had had no previous venereal incident and the remainder had had no less than 42 previous attacks of gonorrhoea, seven of non-gonococcal urethritis, two of syphilis, two of soft sore, and one each of balanitis, genital warts, hydrocele, and nonspecific proctitis-total 57 previous incidents. The eleven West Indians (only three of whom had had no previous trouble) accounted for 41 incidents and averaged 3.7 previous attacks each compared with $1 \cdot 2$ for the remainder.

Management.- In all cases gonococci were found by Gram-stained urethral smear before treatment and in some cases cultures were also made. The routine Wassermann reaction and VDRL (or Kahn) test were both negative in 21 cases, while the Wassermann reaction was negative and the VDRL test positive in three West Indian patients.

Ten patients had failed to respond to doses of 0.5 g. ampicillin, four to $0.75 \mathrm{~g}$., six to $1 \mathrm{~g}$., and four to $2 \mathrm{~g}$. Those receiving $2 \mathrm{~g}$. had been given two doses of $1 \mathrm{~g}$. at an interval of 5 to $6 \mathrm{hrs}$ and the remainder had received the antibiotic in a single dose.

Re-treatment consisted of a single intramuscular injection of 1.2 mega units aqueous procaine penicillin in 21 cases. One patient was given two such injections on successive days and two had single injections of 0.9 m.u. Re-treatment was undertaken within 1 to 3 days of the first treatment in eight cases, within 4 to 7 days in six, 8 to 14 days in four, 15 to 21 days in three, and 22 to 28 days in three.

After re-treatment the patients were instructed to attend for assessment after 2 to 3 days. It was intended they should be seen thereafter at 7, 14, 21,
28,56 , and 90 days from treatment, and at each attendance they were to be examined for urethral discharge, a smear being taken if present, and the urine inspected for haze and threads; at least one examination of the prostatic secretion was planned during surveillance. By no means all patients, however, attended at the times requested.

Follow-up and Results (Table I).-Of 22 patients followed there were seven failures within 14 days from treatment ( 31.8 per cent. of those followed). No satisfactory criteria exist to distinguish relapse from re-infection apart from a history of no further sexual intercourse. Of the failing cases three were in Negroes and four in other persons indicating no significant differences between the two groups.

TABLE I

RESULTS OF RE-TREATMENT WITH PROCAINE PENICILLIN OF FAILURES WITH AMPICILLIN

\begin{tabular}{|c|c|c|c|c|c|}
\hline \multirow{2}{*}{$\begin{array}{l}\text { Length of } \\
\text { Follow-up } \\
\quad \text { (days) }\end{array}$} & \multirow{2}{*}{$\begin{array}{l}\text { No. } \\
\text { Followed }\end{array}$} & \multicolumn{4}{|c|}{ Result } \\
\hline & & \begin{tabular}{|} 
Satis- \\
factory
\end{tabular} & $\begin{array}{c}\text { Non- } \\
\text { gonococ- } \\
\text { cal } \\
\text { Infection }\end{array}$ & $\begin{array}{c}\mathrm{Re}- \\
\text { infection }\end{array}$ & Failure \\
\hline $\begin{array}{c}0 \\
1-3 \\
4-7 \\
8-14 \\
14-21 \\
22-28 \\
29-56 \\
57-90 \\
\text { More than } 90\end{array}$ & $\begin{array}{r}24 \\
22 \\
19 \\
11 \\
4 \\
- \\
2 \\
1\end{array}$ & $\begin{array}{l}\overline{2} \\
2 \\
2 \\
1 \\
= \\
=\end{array}$ & $\begin{array}{l}\frac{z}{3} \\
= \\
= \\
=\end{array}$ & $\begin{array}{l}\bar{Z} \\
\overline{2} \\
\frac{1}{\overline{1}} \\
1\end{array}$ & $\begin{array}{l}\overline{1} \\
\mathbf{3} \\
\mathbf{3} \\
= \\
= \\
=\end{array}$ \\
\hline Total & 22 & 7 & 3 & 5 & 7 \\
\hline
\end{tabular}

In the treatment of the seven cases which failed a second time penicillin was used in four. In one case the condition apparently cleared after a further injection of 0.9 m.u. procaine penicillin. In one case a third failure followed 1.2 m.u. aqueous procaine penicillin, and tetracycline then caused the gonococcus to disappear, but further treatment was required for a non-gonococcal infection. In one case, success was achieved with three daily injections of $1 \cdot 2$ m.u. aqueous procaine penicillin. In the fourth case a satisfactory response was noted following $1 \cdot 2$ m.u. aqueous procaine penicillin plus $1 \mathrm{~m} . \mathrm{u}$. crystalline benzyl penicillin.

In one case streptomycin sulphate $(1.0 \mathrm{~g}$.) was used but further failure ensued and the condition was finally cleared by a single injection of actinospectacin.

Another case responded to tetracycline.

The remaining patient-who was given chloramphenicol-defaulted before a final assessment could be made, 


\section{(2) Failures After Procaine Penicillin Re- TREATED WITH AMPICILLIN}

Cases. - 24 male patients with acute gonorrhoea were failures to treatment with aqueous procaine penicillin. Ten were Negroes from the West Indies, ten were born in the United Kingdom, and one each came from Austria, Eire, Greece, and Italy; five were married and nineteen were single. Their average age was $26 \cdot 5$ years (range 16 to 43 ).

Only fifteen patients had had no previous venereal incident. The remainder had had no less than 35 previous attacks of gonorrhoea (one rectal), nineteen of non-gonococcal urethritis, two of syphilis, and one of anxiety concerning venereal disease-a total of 57 incidents. The ten West Indian patients, four of whom had had no previous incident, accounted for 52 of these and thus averaged $5 \cdot 2$ previous attacks compared with only 0.4 each for the remainder.

Management.-In all cases gonococci were found by Gram-stained urethral smear before treatment. Cultures were made in all but two cases, and sensitivity tests were made in the thirteen cases in which gonococci were satisfactorily grown. The routine Wassermann reaction and VDRL (or Kahn) test were negative in all cases.

All had been treated by aqueous procaine penicillin. In 22 , single injections of 1.2 m.u. had been given; one had 0.9 m.u., and another had three injections of an unknown amount. Three patients, in addition to failing with $1 \cdot 2 \mathrm{~m}$.u. procaine penicillin, had also failed with other antibiotics, two with a single intramuscular injection of $1 \mathrm{~g}$. streptomycin sulphate, and one with one intramuscular injection of $1 \mathrm{~g}$. chloromycetin succinate.

Re-treatment consisted of $1 \mathrm{~g}$. ampicillin given orally under supervision with a further dose of $1 \mathrm{~g}$. to be taken after 5 to 6 hours. Re-treatment was undertaken within 1 to 3 days of the first treatment in eight cases, within 4 to 7 days in eight, within 8 to 14 days in five, within 15 to 21 days in two, and after 6 weeks in one. The subsequent observation planned was similar to that adopted in the first series, but default rates were likewise high.

Follow-up and Results(Table II). - Thus, of eighteen patients followed, there were three apparent failures (16.7 per cent. of those followed); one of these was a Negro.

One patient was re-treated for the further failure with streptomycin and defaulted, in one response was apparently finally obtained with 2.4 m.u. procaine penicillin with aluminium monostearate; and in the third the failure was reported from another hospital and the subsequent progress is unknown.
TABle II

\begin{tabular}{|c|c|c|c|c|c|}
\hline \multirow[b]{2}{*}{$\begin{array}{l}\text { Length of } \\
\text { Follow-up } \\
\quad \text { (days) }\end{array}$} & \multirow[b]{2}{*}{$\begin{array}{l}\text { No. } \\
\text { Followed }\end{array}$} & \multicolumn{4}{|c|}{ Result } \\
\hline & & $\begin{array}{c}\text { Satis- } \\
\text { factory }\end{array}$ & $\begin{array}{c}\text { Non- } \\
\text { gonococ- } \\
\text { cal } \\
\text { Infection }\end{array}$ & $\begin{array}{c}\mathbf{R e}- \\
\text { infection }\end{array}$ & Failure \\
\hline $\begin{array}{c}0 \\
1-3 \\
4-7 \\
8-14 \\
15-21 \\
22-28 \\
29-56 \\
57-90 \\
\text { More than } 90\end{array}$ & $\begin{array}{r}24 \\
18 \\
15 \\
12 \\
6 \\
6 \\
2 \\
1 \\
1\end{array}$ & $\begin{array}{l}\overline{1} \\
3 \\
\frac{3}{3} \\
\\
\end{array}$ & $\begin{array}{l}\frac{5}{1} \\
\frac{1}{2} \\
\frac{1}{-}\end{array}$ & $\begin{array}{l}= \\
= \\
\bar{z} \\
\overline{1}\end{array}$ & $\begin{array}{l}\frac{-}{2} \\
\frac{1}{1 *} \\
=\end{array}$ \\
\hline Total & 18 & 10 & 4 & 1 & 3 \\
\hline
\end{tabular}

* Was heralded by a complicated epididymitis without gonococci at 13 days, which was treated with tetracycline.

\section{Comparison of the Two Series}

Table III shows that, within the statistical limits of the small numbers involved, the results of re-treating failures to aqueous procaine penicillin with ampicillin have to date been better than those of re-treating failures to ampicillin with aqueous procaine penicillin.

TABLE III

COMPARISON OF THE TWO SERIES

\begin{tabular}{|c|c|c|c|c|c|c|}
\hline \multirow[b]{2}{*}{$\begin{array}{c}\text { First } \\
\text { Treatment }\end{array}$} & \multirow[b]{2}{*}{$\underset{\text { Treatment }}{\text { Second }}$} & \multirow[b]{2}{*}{$\begin{array}{c}\text { No. } \\
\text { Treated }\end{array}$} & \multirow[b]{2}{*}{$\begin{array}{l}\text { No. } \\
\text { Followed }\end{array}$} & \multicolumn{3}{|c|}{ Result } \\
\hline & & & & $\begin{array}{c}\mathrm{Re}- \\
\text { infection }\end{array}$ & $\begin{array}{r}\mathrm{Fa} \\
\text { No. }\end{array}$ & lure \\
\hline Ampicillin & $\begin{array}{l}\text { Procaine } \\
\text { penicillin }\end{array}$ & 24 & 22 & 5 & 7 & $31 \cdot 8$ \\
\hline $\begin{array}{l}\text { Procaine } \\
\text { penicillin }\end{array}$ & Ampicillin & 24 & 18 & 1 & 3 & $16 \cdot 7$ \\
\hline
\end{tabular}

\section{Sensitivity Tests}

Tests of sensitivity to various antibiotics, using a disk method, were made against the cultured gonococcus in sixteen cases, thirteen of whom were patients who had failed to procaine penicillin and were about to be treated with ampicillin (Table IV).

TABLE IV

ANTIBIOTIC SENSITIVITY TESTS

\begin{tabular}{|c|c|c|c|c|c|c|}
\hline \multirow{2}{*}{ Antibiotic } & \multicolumn{4}{|c|}{ Sensitivity } & \multirow{2}{*}{$\begin{array}{l}\text { Total } \\
\text { Cases }\end{array}$} & \multirow{2}{*}{$\begin{array}{l}\text { Per cent. } \\
\text { Less } \\
\text { Sensitive }\end{array}$} \\
\hline & ++ & + & \pm & 0 & & \\
\hline $\begin{array}{l}\text { Penicillin . } \\
\text { Streptomycin } \\
\text { Chloramphenicol. } \\
\text { Tetracycline } \\
\text { Erythromycin } \\
\text { Sulphonamides } \\
\text { Methicillin } \\
\text { Ampicillin }\end{array}$ & $\begin{array}{r}13 \\
5 \\
16 \\
16 \\
16 \\
12 \\
2 \\
3\end{array}$ & $\begin{array}{l}\frac{3}{-} \\
\frac{2}{2} \\
\frac{1}{1}\end{array}$ & $\begin{array}{l}-3 \\
- \\
- \\
-\end{array}$ & $\begin{array}{l}\overline{8} \\
- \\
- \\
-\end{array}$ & $\begin{array}{r}16 \\
16 \\
16 \\
16 \\
16 \\
14 \\
2 \\
4\end{array}$ & $\begin{array}{c}\mathbf{1 8} \cdot \mathbf{8} \\
\mathbf{6 8} \cdot \mathbf{8} \\
\mathrm{Nil} \\
\mathrm{Nil} \\
\mathrm{Nil} \\
\mathbf{1 4} \cdot \mathbf{2}\end{array}$ \\
\hline
\end{tabular}


The most striking findings concerned streptomycin; no less than $68 \cdot 8$ per cent. of the tested strains showed a lessened sensitivity to streptomycin and 50 per cent. showed complete resistance. With penicillin $18 \cdot 8$ per cent. showed a lessened sensitivity. No change was noted in respect of any strains tested against chloramphenicol, tetracycline, or erythromycin. Even with sulphonamides only $14 \cdot 3$ per cent. of strains showed a lessened sensitivity in vitro.

The disk method used, however, is not well adapted to demonstrate slight falls in sensitivity although it is a useful guide when complete resistance occurs, as with streptomycin.

\section{Summary AND Conclusions}

(1) Some of the facets of failure to antibiotic treatment of gonorrhoea are reviewed. It has been suggested that ampicillin may be more active than benzyl penicillin against gonococci less sensitive to penicillin.

(2) To test this hypothesis, the results of re-treating with aqueous procaine penicillin 24 male patients with gonorrhoea, who had failed to be cured by ampicillin were compared with those of re-treating with ampicillin 24 other patients who had failed to be cured by procaine penicillin.

(3) Of 24 treated unsuccessfully with ampicillin and re-treated with procaine penicillin, 22 were followed and there were seven failures within 2 weeks ( $31 \cdot 8$ per cent. of those followed). Of 24 treated unsuccessfully with procaine penicillin and re-treated with ampicillin, eighteen were followed and there were only three failures ( 16.7 per cent.).

(4) Within the limits of the numbers involved the results of re-treatment with ampicillin were thus better than those of re-treatment with procaine penicillin.

(5) The results of tests of sensitivity to antibiotics in a number of the cases are described. Only $18 \cdot 8$ per cent. of the strains tested by a disk method showed a lessened sensitivity to penicillin, but reduced sensitivity to streptomycin was noted in no less than 68.8 per cent. and complete resistance in 50 per cent.

\section{REFERENCES}

Cradock-Watson, J. E., Shooter, R. A., and Nicol, C. S. (1958). Brit. med. J., 1, 1091.

Curtis, F. R., and Wilkinson, A. E. (1958). Brit. J. vener. Dis., 34, 70.

Durel, P. (1961). Ibid., 37, 107.

Gjessing, H. C. (1962). Nord. Med., 67, 119.

__ and Ödegaard, K. (1962). Acta derm.-venereol. (Stockh.), 42, 305.

Letchner, E. H., and Nicol, C. S. (1961). Brit. J. vener. Dis., 37, 158.

Mead, R. K., Moon, N. F., and Bean, L. L. (1960). U.S. armed Forces med. J., 11, 1117.

Medical Research Council (1961). Lancet, 2, 226.

Morton, R. S. (1963). Brit. J. vener. Dis., 39, 105.

Ödegaard, K. (1962). Brit. med. J., 1, 645.

Reyn, A. (1961). Ugeskr. Laeg., 123, 776.

-, Korner, B., and Bentzon, M. W. (1958). Brit. J. vener. Dis., 34, 227.

Röckl, H. (1962). Münch. med. Wschr., 104, 1169.

Roiron, V., Rasetti-Nicod, G., and Durel, P. (1961). Ann. Inst. Pasteur, 100, 445.

Sabath, L. D., and Kivlahan, J. J. (1961). Amer. J. med. Sci., 242, 663.

Thayer, J. D., Field, F. W., Perry, M. I., Martin, J. E., and Garson, W. (1961). Bol. Ofic. sanit. panamer., 51, 346.

Willcox, R. R. (1961). Bull. Wld Hlth Org., 24, 307.

Rechute de la blennorragie traitée par la pénicilline, et réponse à la procaīne benzyl pénicilline $G$ et à l'ampicilline RÉSUMÉ

(1) L'auteur passe en revue certains aspects des rechutes de la blennorragie traitée par les antibiotiques. On suggère que l'ampicilline (A) aurait plus de succès contre les gonococques moins sensibles à la pénicilline que la procaïne benzyl pénicilline (B).

(2) On compare les résultats du traitement en deux groupes de malades:

I. 24 qui ne furent pas guéris par (A) furent traités de nouveau par (B).

II. 24 qui ne furent pas guéris par (B) furent traités de nouveau par (A).

(3) Du premier groupe, 22 furent suivis et il y eut 7 rechutes en deux semaines $(31,8 \%)$.

Du deuxième groupe, 18 furent suivis et il $y$ eut 3 rechutes $(16,7 \%)$.

(4) Donc, parmi les petits nombres étudiés, (A) eut plus de succès que (B).

(5) On rapporte les résultats des tests de sensibilité aux antibiotiques divers dans plusieurs cas. Seulement $18,8 \%$ des souches étudiées par une méthode à disque se montrèrent moins sensibles à la pénicilline, mais $68,8 \%$ furent resistantes à la streptomycine, et pour $50 \%$ cette résistance fut absolue. 